\title{
WOMEN AND THE EPISTEMOLOGY OF CORPORATIONS LAW
}

\author{
PETA SPENDER ${ }^{*}$
}

\author{
INTRODUCTION
}

\begin{abstract}
Some progress has already been made in law schools away from a rationalist model of knowledge which elevates a single, normative paradigm. Many law teachers now recognise that the imposition of a singular knowledge (claiming to be "truth" and legitimated by this claim) which either devalues, or excludes altogether, the perspectives and experiences of women and visible minorities, raises critical equity questions. Not only is this vision of knowledge exclusionary and inequitable in its effect but it is also incomplete and deficient, excluding as it does persons and alternate views of the world and suppressing a spirit of critique. ${ }^{1}$
\end{abstract}

In order to effect changes to law school culture, it is critical that the central epistemological assumptions of legal education be challenged. Gender analysis is valuable for corporations lawyers because it provides a way to challenge the epistemology which is fundamental to corporate law scholarship. This article proposes to locate the participation of women in corporations law. In doing so, it suggests that the "knowledge" of corporations law which is taught in Australian law schools masks the experiences of women in this area.

When one begins to explore the issue of gender and corporations law, one's immediate impression is that women are invisible. The protagonists in both corporate activity and corporations law always seem to be men. ${ }^{2}$ Corporations law is based upon a philosophy of liberal autonomy which has as its basic premise the self-interested male. The law has sought to preserve the liberal philosophy in this area and has regulated behaviour only when individual self-interest has caused certain kinds of quantifiable harms. Implicit and explicit in the law of corporations are such values as competition, hierarchy aggression and strict classification of roles. ${ }^{3}$ Naffine has argued that while the law purports to deal in abstract individuals, in truth it has a preferred person: the man of law, the individual who flourishes in, and dominates the type of society conceived by law. She describes him as follows:

He is one of the possessing classes. His gender takes the form of a certain exaggerated style of middle-class masculinity: he is assertive, articulate, independent, calculating, competitive and competent. And these are precisely the qualities valued in the sort of society which law has in mind: a society which is fiercely competitive and composed of similarly self-interested and able individuals; a society which looks very much like the modern free market. $^{4}$

This "preferred person" reaches the pinnacle of his career in corporations law. He is derived from the cases, the texts, the articles but most importantly from the business culture which informs the development of the law of corporations. The discourses of business and law intersect at corporations law and each plays a critical role in the development of hegemonic masculinity. ${ }^{5}$

Another important factor in the epistemology of corporations law is its place within the doctrinal boundaries created in the law school curriculum. The doctrinal ambit of corporations law "knowledge" is narrow. Women will come into contact with corporations in many different ways, but they will not be classified as being within the realm of corporate law. For example, women will be employees of corporations, but this is the province of industrial law or employment law. They will also come into contact with the company as involuntary creditors if they suffer an injury caused by the company but this will be in the province of tort law. They might be joining the company in a divorce property settlement but this will be the realm of family law. By contrast, corporations law is defined as a specific area involving human beings participating in companies as officers or shareholders or outsiders dealing with the company as a separate legal subject, for example as creditors. Thus its ambit is narrow and women appear to be invisible. 
Consequently applying a gender analysis to corporations law requires locating women in business as well as corporations law. ${ }^{6}$ It also requires an expansive interpretation of the proper ambit of "corporations law". Although gender analysis of corporations law both in Australia and internationally is still in its infancy ${ }^{7}$ it is one mechanism by which to challenge hegemonic masculinity.

This challenge reveals that women are not absent from either corporations or corporations law, rather they are excluded by a rationalist model of knowledge which reflects a narrow view of what is "real" knowledge and fails to reflect the conditions of a pluralist society. ${ }^{8}$ If women are only invisible and not absent, it is necessary either to find them or to explain their lack of visibility. Broadly speaking, a gender analysis of corporations law can be undertaken by looking at 3 categories, based on the extent of participation of women. The categories are as follows:

- Primary Participation - where women form their own companies. The evidence which is available indicates that they are forming small businesses at a rate which is greater than that of men. ${ }^{9}$ In this category women will fulfil both the managerial and ownership roles.

- Secondary Involvement - where women are involved in companies formed and managed by men. They will generally be involved in some familial relationship with the proprietor of the company. For instance, one situation which has lead to much recent discussion is the plight of women who are recruited by their male partners to act as the second director of the family company. Their involvement in the company is intended to be either nonexistent or passive, but the law imposes substantial personal liability upon them

- Non-Participation - where there is statistically insignificant participation by women. In this category are the large corporations, particularly public companies which are characterised by separation of ownership from control, and bureaucratic decision making.

The legal concept of separate legal personality gathers momentum as we move through this hierarchy of participation. So it will have the greatest content where women do not participate, ie it is most meaningful when the corporation is large. At the secondary level, it works to enable the male proprietor form the company itself, but then the law uses devices such as s 588G Corporations Law to create personal liability for the passive recruited director. At the point of primary participation by women, separate legal personality is meaningless because the ventures are almost always small and women are required to provide more personal guarantees than their male counterparts, frequently involving greater use of third party guarantees. ${ }^{10}$

\section{PRIMARY PARTICIPATION}

The empirical evidence indicates that women are more successful than men in self employment, measured in terms of repayment of debt, better and earlier profitability and long-term business survival. ${ }^{11}$ It is also important that businesses set up by women are the fastest growing sector for small business. In 1993, information supplied by the National Small Business Centre indicated that women were setting up small businesses at a rate three times faster than men and had the potential to outnumber men as small business owners. ${ }^{12}$ Possibly more women are undertaking this path because of the glass ceiling and the restrictions placed upon women in conventional organisational careers. The move was described by Susan Ryan as "an imaginative response to a women's own career path."13

What type of business association would these women seek?

Leonie Still has undertaken some work in this area which found that the majority of women who are self-employed in Australia are either "solo operators" (where the business has no employees) or owners of micro-businesses (where the business has up to 5 employees). She found that generally speaking selfemployed women are "small business owners" rather than "entrepreneurs". ${ }^{14}$ She writes:

Whilst the "entrepreneur" title is more attractive to women, and they do have entrepreneurial flair, their businesses are small and remain small because they like to keep control. ${ }^{15}$ She concluded that entrepreneurial risk-taking and growth did not usually apply to women's enterprise ventures. Conversely, she found that 90 per cent of Australian women's businesses fit the following description: they are independently owned

- they are closely controlled by the owner/manager, who has prime responsibility for the firm's principal decisions

- the owner/manager has contributed most, if not all, of the operating capital 
- the firm's operations are usually locally based, although its market might not be

A study undertaken by Still, Guerin and Chia found that business proprietorship also gives women a means of simultaneously accommodating their work and greater childcare responsibilities. Thus, selfemployment enables women to become independent and autonomous in their own career management. ${ }^{16}$

This research suggests that women associate in different ways to men. However, we do not know whether women voluntarily assume these business forms or they are imposed upon them. Thus, interpreting Still's work takes us directly into the debate between Carol Gilligan and Catherine MacKinnon. Carol Gilligan argued that women deal with problems in terms of a narrative of relationships which extend over time. Males, by comparison deal with moral problems like a maths problem, ie they set up the equation in terms of the various rights involved and set about working out the solution. ${ }^{17}$

Gilligan's work is highly contentious from the point of view of both her methodology and her conclusions. Writers such as MacKinnon strenuously disagree with her conclusions because they argue that Gilligan has failed to identify the causal mechanism of the different voice, which is the subordination of women. MacKinnon argues that Gilligan's analysis appears to celebrate this oppression without taking account of power. ${ }^{18}$

Nevertheless, Gilligan's analysis does have proponents. One such proponent is Theresa Gabaldon who has provided a critique of limited liability based on relational feminism. Applying the "connectedness" argument, she states that a feminist typically would not dichotomise "productive" and other forms of organisation or separate monetarily remunerated work from the rest of her life. ${ }^{19}$

In her view, efforts to produce food, clothing, forms of amusement and other goods and services should accommodate and incorporate relationships with children and other loved ones and should permit an actor to express care and concern even for those with whom she is not intimately involved. ${ }^{20}$

So, according to Gabaldon, an organisation conceived by feminists would not feature limited liability because limiting liability is about imposing risks that someone else might bear. This artificially distances individuals from the real life effects of the enterprise in which they invest, thus decreasing their acknowledged personal responsibility.

If we extend Gabaldon's argument to the general issue of women's enterprise, we would argue that women are forming these types of business associations because they wish to operate in the context of a narrative of relationships and therefore resist the separation of ownership from control. Still's research appears to support this theory, since there appears to be an element of women choosing not to expand their business enterprises so as to cause a separation of ownership from control.

What are the consequences of this for legal doctrine? One argument is that a relational association significantly undermines separate legal personality. In other words, it is inappropriate to create a separate legal creature because women's businesses are based on personal responsibility. ${ }^{21}$

It is also important to note that concepts such as relational association have permeated the mainstream. Last year the Harvard Business Review published an article by Rosabeth Moss Kanter which presented conclusions derived from her research into international corporate alliances. It urged the development of intercompany relationships based on nurturing rather than control. As stated in the article:

Intercompany relationships ... seem to work best when they are more familylike. Obligations are more diffuse, the scope for collaboration more open, understanding grows between specific individuals, communication is frequent and intensive, and the interpersonal context is rich. The best intercompany relationships are frequently messy and emotional, involving feelings like chemistry and trust. And they should not be entered into lightly Only relationships with full commitment on all sides endure long enough to create value for the partners. ${ }^{22}$

\section{SECONDARY PARTICIPATION}

In this category, corporate law plays a more prominent role. A common situation arose where the male spouse formed a company and needed another family member to fulfil the minimum statutory requirement of two directors. ${ }^{23}$ Often that family member was the female partner of the sole trader. The woman who was recruited to fulfil the statutory requirement was very often a passive director, since the expectation of both directors was that the sole trader would have the carriage of the business. ${ }^{24}$

The role of the passive director has received considerable attention by the judiciary in the last few years. 
Of greatest importance have been the cases dealing with insolvent trading, ${ }^{25}$ in the context of which the judiciary has issued some strong warnings about the standard of care which is required of directors. These cases typically involved a recruited female director of an incorporated sole trader or small family company. She was ignorant of her duties as a company director and left the running of the business to a male spouse or other family member. No board meetings were held and generally the female director had played no active role in the management of the company apart from signing documents supplied by the primary director or taking telephone calls or other acts of a minor administrative nature. In each of the cases the company became insolvent and a creditor sued the passive director as being personally liable under s 588G Corporations Law and its predecessors. Overwhelmingly, the judges held that women should have full liability as directors.

The s 588G cases are important on one level because they raise the dilemma of whether women directors should be treated the same as males or that their special situation requires special treatment. ${ }^{26}$ However, these cases also demonstrate the difficulty faced by the courts in adjudicating the competing claims of families and creditors to corporate assets. The family's role as repository of corporate assets should not be underestimated, because the family plays a significant role in immunising assets from creditors.

More fundamentally, the cases demonstrate the way in which the formal abstract body of corporate law allows for the gendered separation of business matters and the family It is the formality of much of corporate law which leaves it open to manipulation and allows the managers to develop considerable intellectual capital by being the only person who understands the way in which the business operates. The formality of company law allows the corporate form to be used without the need for actual participation in the business by secondary partners. In this sense, the corporation plays a crucial role in maintaining the distinction the public and private spheres. Further, in the private sphere, women service the corporate moral order which is revealed in the public sphere. In other words, women manage the moral order in a way which mirrors their spouses' agency within the corporate structure. ${ }^{27}$

Most importantly for present purposes, the s 588G cases demonstrate the need to further develop the linkages between corporate law and the family The family has until recently been conspicuously absent from corporate law research. This in itself demonstrates the gendered nature of legal scholarship. One very significant area is the involvement of the corporation in the adjudication of family law disputes. The creation of the family company means that there may potentially be three contestants in any family court proceedings. The corporation therefore informs the adjudication of the rights between the female and male spouses. ${ }^{28}$

\section{NON PARTICIPATION}

The larger the corporation, the less likely that women will be involved in any capacity other than passive investment. There has been no lack of material over the last 15-20 years which has been addressed to women dealing with how to succeed in male-dominated institutions. In fact, for a long time, this was the dominant discourse in the area of women and corporations. However, the statistical data indicates that the participation of women on the boards of large corporations has remained static at about three to four percent of all board members; one percent of executive directors and five percent of non-executive directors. ${ }^{29}$ This would appear to indicate that the organisational structures in large corporations are hostile to women.

What is the legal ramification of this? Clearly the low participation indicates the need for more flexible organisational structures which allow women to define a particular relationship between themselves and large corporations. Arguably, anti-discrimination and affirmative action legislation has proved ineffective to deal with the problems faced by such women. However, the overall extent to which legal doctrine contributes to the hostile culture is unclear.

\section{CONCLUSION}

In 1985 Kathleen Lahey and Sarah Salter made the following comment about the participation of women in corporations law: 
Women academics sometimes admit that they feel a comfort in corporate law that is not available to them in other, more apparently personal, areas of law. The invisibility of women in capitalist discourses is a comfort, for women are only infrequently participants ... Issues of oppression and power relations arise only between rich white males; the whole drama of corporate law thus has an air of unreality, a sort of legal "star wars". 30

This very aptly describes the effect of the vision of knowledge of corporations law as taught in law schools. It is a vision of knowledge which is rationalist and based on the experience of a single, dominant group. Such a rationalist epistemology conceives knowledge as fixed, certain and detached from social context. ${ }^{31}$ The discussion above reveals that the women are by no means absent from corporations law, rather they are integral players, but we need to look around the corporation in order to see them. This can be complicated, because it requires ascribing value to the particular roles undertaken by women in this area, as well as overcoming personal assumptions about what the law is or should be. As stated by Macfarlane:

Reflecting on our own assumptions as teachers of law about the appropriate content and process involves examining the central significance of epistemology to education from a personal standpoint. It is not always easy to recognise the reflection of our personal conceptions of knowledge and truth in our teaching practice or the assumptions we make about the subjects we teach... In order to reassess our teaching ... it is necessary for us as teachers to question many, if not all of our assumptions about legal education and the form it should take.

* Faculty of Law, Australian National University. (C) 1996. (1995) 6 Legal Educ Rev 195.

1 J Macfarlane, A Feminist Perspective on Experience-Based Learning and Curriculum Change (1994) Ottawa L Rev 357, at 359-60.

2 This applies to men appearing as individual litigants and as the embodiment of the corporation. For examples of the latter see Brick and Pipe Industries Ltd v Occidental Life Nominees Pty Ltd (1992) 10 ACLC 253, Whitehouse v Carlton Pty Ltd (1987) 5 ACLC 407.

3 V Held, Feminist Transformations of Moral Theory (1990) 50 Phi1 \& Phenomenological Res 321, at 321.

4 N Naffine, Law and The Sexes (Sydney: Allen \& Unwin, 1990) 22.

5 M Thornton, Women and Legal Hierarchy (1989) 1 Legal Educ Rev 97, at 98 refers to this term which was originally used by RW Connell, Gender and Power (Sydney: Allen \& Unwin, 1987) 184. The term "hegemonic masculinity” borrows from Gramsci and may be defined as "a social ascendancy achieved in a play of social force that extends beyond contests of brute power into the organisation of private life and cultural processes".

6 A recent survey of 5000 businesses commissioned by Price Waterhouse and the Commonwealth Bank indicates that a very large percentage of business is conducted through corporations. This survey revealed that 79.9 per cent of businesses are private companies, 1.9 per cent are companies on the Australian Stock Exchange, 9.6 per cent family trusts, 6.7 per cent partnerships and 1.9 per cent sole traders. See Succession troubles ahead (1995) 11 Company Director (No 6) 20, at 21.

7 However, this area of research is developing momentum and has been explored in the following papers: KA Lahey \& SW Salter, Corporate Law in Legal Theory and Legal Scholarship: From Classicism to Feminism (1985) 23 Osgoode Hall LJ 543, at 570; TA Gabaldon, The Lemonade Stand: Feminist and Other Reflections on the Limited Liability of Corporate Shareholders (1992) 45 Vanderbilt L Rev 1387; R Cohen, Feminist Thought and Corporate Law: It's Time To Find Our Way Up From the Bottom (Line) (1994) 2 J Gender \& L 1; KH Hall, Starting From Silence: The Future of Feminist Analysis of Corporate Law (1995) CBLJ 149.

8 Macfarlane, supra note 1 , at 359.

9 S Bagwell, More Women Breaking the “Glass Ceiling” Australian Financial Review 5 October 1993, at 33.

10 LV Still, Where to From here? The managerial woman in transition (Sydney: Business and Professional Publishing, 1993$) 55$.

11 Id at 59.

12 S Bagwell, Why women don’t make it in business Australian Financial Review 27 August 1993, at 1.

13 R Smith \& A O’Neill, Small is Successful Time Australia, 24 October 1994, at 60

14 Still, supra note 10, at 59 defines these terms in the following way. A "small business owner" is working in her own business for the principal purpose of furthering personal goals. An "entrepreneur" is defined as working in her own business for the principal purpose of profit and growth.

15 Id.

16 LV Still, CD Guerin, \& B Chia, Women in Management Series, Self-Employed Women: A Sydney Survey (Sydney: University of Western Sydney, 1990) No 13, at 3.

17 C Gilligan, In a Different Voice: Psychological Theory and Women's Development (Cambridge: Harvard University Press, 1982)

18 CA MacKinnon, Feminism Unmodified: Discourses on Life and Law, (Cambridge: Harvard University Press, 1987) 38-39.

19 It should be noted that Gilligan's work has been criticised as being essentialist and this criticism could also be directed to the theories proposed by Galbaldon. The antiessentialist critique of feminist theory is concerned with the unitary categorisation of women, regarding such categorisation as indeterminate or unstable, as well as having potentially negative social consequences: A Harris, Race and Essentialism in Feminist Legal Theory (1990) 42 Stan L Rev 581; K Abrams, Title VII and the Complex Female Subject (1995) 94 Mich L Rev 2479; Caroline Forell, Essentialism, Empathy and the Reasonable Woman (1994) U Ill L Rev 769.

20 Gabaldon, supra note 7, at 1428-29.

21 Lahey \& Salter, supra note 7, suggest that women's enterprises might use "lock-ins", which reverse the notion of the free transferability of shares. This would mean that people would have to be careful about their initial choices as shareholders.

22 RM Kanter, Collaborative Advantage: The Art of Alliances (1994) 72 Harv Business Rev 96, at 100.

23 The requirement of two directors under s221 Corporations Law has been changed to one director by the First Corporations Law Simplification Act 1995 (Cth). Although this removes the statutory requirement for proprietors to recruit women from within their 
family as the second director, it is unclear whether the requirement will nevertheless be imposed for commercial reasons, for example by creditors. Further, women will still retain extensive secondary liability for the debts of the corporation through devices such as guarantees.

24 The importance of this arrangement cannot be underestimated. A survey of 5000 businesses commissioned by Price Waterhouse and the Commonwealth Bank, referred to supra note 6, at 20, revealed that family-owned businesses account for 83 per cent of all businesses. Of that 83 per cent, 79.9 per cent are private companies. Forty seven per cent of these companies have 2 shareholders, 32.6 per cent have between 3 and 5, 9.2 per cent have between 6 and 10 and the remaining 4.4 per cent have more than 10 shareholders.

25 Metal Manufacturers Ltd v Lewis (1988) 13 ACLR 357; Statewide Tobacco Services v Morley (1990) 2 ACSR 405; Heide Pty Ltd $v$ Lester (1990) 8 ACLC 958, Group Four v Brosnan (1992) 8 ACSR 463; Standard Chartered Bank of Australia v Antico (1995) 13 ACLC 1381.

26 For a thorough and interesting analysis of this issue, see J Dodds Streeton, Feminist Perspectives on the Law of Insolvency Aspects of Real Property and Insolvency Law, Adelaide Law Review, Research Paper No 6, 1994. Dodds at 12 explores the problem of the dissonance between women's legal capacity and the reality of their status in a commercial and social context. If women are treated as a vulnerable category per se, this would entail the reintroduction of limits on legal capacity, either absolute or partial, prohibiting women from entering sureties or related transactions. Such an option sacrifices the considerable gains constituted by formal legal equality and is therefore unacceptable from a feminist perspective. Another option is to preserve women's equal legal capacity but offer protection through flexible legislation and case law predicated on a recognition of their likely social vulnerability. Such protection, if too extensive or inflexible would be counter-productive because creditors would refuse to deal at all with women in surety transactions.

27 D Smith, Women, the Family and Corporate Capitalism, in M Stephenson ed, Women in Canada (Toronto: New Press, 1973$) 17$.

28 Ascot Investments v Harper (1980-1981) 148 CLR 337; In the Marriage of Ferraro (1992) 16 Fam LR 1.

29 Korn/Ferry International and the Australian Institute of Company Directors, Fourteenth Study of Boards of Directors, (1995). This survey covered 194 Australian private and public companies. It found that only 24 per cent of these companies had female directors. The same trend seems to be occurring in the United Kingdom: see V Holton, Surveying the Situation for Women Directors in the UK (1995) 3 Corporate Governance Reports 102. However, compare these studies to a survey by Fortune magazine in the USA, which showed that of the 100 corporations which had had improved sales last year, 95 had at least one female director: J Foreshaw \& E Moody, Noisy old boys drown out women Australian 6 December 1995, at 35.

30 Lahey \& Salter, supra note 7, at 570.

31 Macfarlane, supra note 1 , at 362 